\title{
The novel HSV-1 $U_{5} 5-1$ RNA is transcribed off a domain encoding $U_{S} 5, U_{S} 4, U_{S} 3, U_{S} 2$ and $a 22$
}

\author{
Vladimir Jovasevic and Bernard Roizman*
}

\begin{abstract}
Background: The genome of herpes simplex virus 1 encodes at least 84 transcripts from which proteins are translated and several additional RNAs whose status as mRNAs is unknown. These RNAs include latency-associated transcript, $\mathrm{Ori}_{S} 1$ and $\mathrm{Ori}_{S} 2 \mathrm{RNAs}$ and in case of a4 null mutant additional transcript that spans the junction between $\mathrm{L}$ and $\mathrm{S}$ component of the HSV-1 genome. Current data do not suggest that a peptide is translated from these RNAs.

Results: We describe here a novel RNA designated $U_{5} 5-1$ that spans $4.5 \mathrm{~kb}$ of the unique-short $\left(U_{5}\right)$ region. The RNA initiates in $U_{S} 5$ and terminates in the a 22 open reading frame. It is expressed antisense to $U_{S} 5, U_{S} 4, U_{S} 3$ and ICP22 mRNAs. This transcript is expressed with $\gamma_{2}$ kinetics and has a half-life of 80 minutes.

Conclusion: These results identify a novel transcript encoded within HSV-1 genome. Since no major hypothetical open-reading frames are present in this transcript it is feasible that this RNA exerts its function as a non-coding RNA.
\end{abstract}

\section{Background}

The original report of the organization of the unique short $\left(\mathrm{U}_{\mathrm{S}}\right)$ DNA sequences of the herpes simplex virus 1 (HSV-1) listed 12 open reading frames (ORFs) designated $\mathrm{U}_{\mathrm{S}} 1(\alpha 22)$ through $\mathrm{U}_{\mathrm{S}} 12(\alpha 47)$ [1]. Subsequent studies led to the discovery of three additional transcripts and at least two non coding transcripts. The coding transcripts were $U_{S} 8.5$ mRNA co-terminal with $U_{S} 8$ and $U_{S} 9$ [2], $\mathrm{U}_{\mathrm{S}} 1.5$ co-terminal with the $\alpha 22$ transcript [3], and $\mathrm{U}_{\mathrm{S}} 3.5$ co-terminal with the $\mathrm{U}_{\mathrm{S}} 3$ mRNA [4]. The non coding transcript $\mathrm{Ori}_{S} 1$ initiated in $\alpha 22$ or $\alpha 47$ ORFs, run across the origins of DNA synthesis and terminated at the transcription termination site of the $\alpha 4$ gene. Ori 2 terminated at or near the transcription initiation site of the $\alpha 22$ or $\alpha 47$ gene [5]. Latency-associated transcript (LAT) is the only viral transcript detected in latently infected neurons [6]. Although several potential ORFs can be found within LAT sequence, none of them are transcribed in the context of viral infection $[7,8]$. In addition, Schaffer and colleagues [9] reported transcripts in cells infected

\footnotetext{
* Correspondence: bernard.roizman@bsd.uchicago.edu

${ }^{1}$ The Marjorie B. Kovler Viral Oncology Laboratories, The University of Chicago, Chicago IL 60637, USA

Full list of author information is available at the end of the article
}

with $\Delta \alpha 4$ mutant that spanned the junction between the $\mathrm{L}$ and $\mathrm{S}$ components of HSV-1 DNA. While it is suspected that LAT plays a role in the establishment and maintenance of latent infection, its function is not well established. Also, the roles of $\mathrm{Ori}_{S}$ transcripts or $\Delta \alpha 4$-specific transcript are unknown. In this report we describe an additional long transcript designated $\mathrm{U}_{\mathrm{S}} 5-1$ RNA. As the designation implies, this transcript originates in the $\mathrm{U}_{\mathrm{S}} 5 \mathrm{ORF}$ and terminates in the $\alpha 22 \mathrm{ORF}$.

\section{Results}

RNA antisense to $U_{\mathrm{s}} 3$ is expressed in cells infected with wild-type virus

The experiments reported here resulted from the observation that a mutant derived from R7208 contained an unexplained $1.6 \mathrm{~kb}$ RNA antisense to the $\mathrm{U}_{\mathrm{S}} 3$ ORF. Briefly, in this mutant the $\alpha 22$ gene was deleted and in the course of studies of a selected isolate of this mutant we found that it contained an insertion containing a stop codon upstream of the $\mathrm{U}_{\mathrm{S}} 3$ ORF. To determine whether RNA antisense to $\mathrm{U}_{\mathrm{S}} 3$ is expressed in cells infected with wild-type virus, rabbit skin cells (RSC) were exposed to 10 PFU of HSV-1(F) per cell, RNA was extracted $18 \mathrm{~h}$ later and subjected to RT-PCR or Northern blot analysis. 
For RT-PCR analysis cDNA was generated from total RNA using primer 51(R), specific for RNAs antisense to $\mathrm{U}_{\mathrm{S}} 3$. PCR reaction was performed using the $51(\mathrm{~F})$ as forward and $51(\mathrm{R})$ as reverse primer. While reverse transcription with 51(R) primer would also generate cDNA from $\mathrm{U}_{\mathrm{S}} 2$ transcript, this cDNA would not be amplified under PCR reaction used in this experiment since 51(F) primer lies upstream from $\mathrm{U}_{\mathrm{S}} 2$ transcript (Fig. 1C). Results of RT-PCR analysis (Fig. 2A) show that antisense RNA was also expressed in cells infected with wild-type virus. Northern blot analysis, performed using 1\% agarose gel, (Fig. 2B) verified these results and additionally indicated that in cells infected with the wild type virus the RNA was approximately $4.5 \mathrm{~kb}$ long.

\section{The $\mathrm{U}_{\mathrm{s}} 5-1$ transcript spans genomic region between $\mathrm{U}_{\mathrm{s}} 5$ and $\mathbf{2} 22$}

Experiments were next carried out to determine the region of the $\mathrm{S}$ component spanned by the $\mathrm{U}_{\mathrm{S}} 5-1 \mathrm{mRNA}$. To determine the location of the 5'-end we relied initially on observations carried out on the R7802 recombinant virus. In cells infected with this mutant, the truncated $\mathrm{U}_{\mathrm{S}} 5-1$ RNA terminated at the polyadenylation signal inserted into the $\mathrm{U}_{\mathrm{S}} 2 / \mathrm{U}_{\mathrm{S}} 3$ boundary ( $\mathrm{V}$. Jovasevic. and B. Roizman, manuscript in preparation). Knowing the size of this RNA ( 1.6 kb), we estimated the location of its 5'end on the basis of the assumption that the sequences upstream of the insertion site would be identical in both R7802 and wild-type virus. In order to fine map the location of the 5'-end of the $\mathrm{U}_{\mathrm{S}} 5-1$ transcript, we performed a series of northern blot analyses that helped us place the 5 -end within the sequences covered by the probe 3 (data not shown). To determine more precisely the location of the 5'-end of the $\mathrm{U}_{5} 5-1$ transcript we performed an RNase-protection assay using probe 3 . The results of this experiment reveal the presence of a protected fragment with size of about 270 bases (Fig. 3A, arrow). In figure 1A the sequence of the probe 3 is shown in red and underlined are the first 270 bases of the probe 3 protected in the RNase protection assay. A potential TATA box sequence can be observed upstream from the last underlined base (boxed sequence), making it more likely that the underlined sequence of the probe 3 is the 5 terminus of the $\mathrm{U}_{\mathrm{S}} 5-1$ transcript.

On the basis of the size of the $\mathrm{U}_{\mathrm{S}} 5-1$ transcript and the location of its 5 '-end we estimated the location of the 3'end to be within the ICP22 ORF. To determine more precisely the location of the 3'-end, RSC were infected with 10 PFU of HSV-1(F) per cell, RNA extracted $18 \mathrm{~h}$ later and subjected to RNase protection assay using a probe that spanned the predicted termination site identified within ICP22 ORF (probe 1). The probe 1 protected frag- ment of approximately 180 bases long (Fig. 3B, arrow). In figure $1 \mathrm{~B}$ the sequence of the probe 1 is shown in red and underlined are the last 180 bases of the probe 1 protected in the RNase protection assay. In the vicinity of the identified 3'-end we observed a sequence that could potentially serve as a polyadenylation sequence for the $\mathrm{U}_{\mathrm{S}} 5-1$ transcript (boxed sequence). In addition to the 180 bases long fragment we also observed another protected fragment that was equal in length to the full-length probe. This fragment does not correspond to the $\mathrm{U}_{\mathrm{S}} 5-1$ transcript, considering that the $\mathrm{U}_{\mathrm{S}} 5-1$ transcript is $\sim 4.5 \mathrm{~kb}$ long. It is possible that a different RNA, expressed antisense to ICP22, is present in infected cells.

Figure $1 \mathrm{C}$ illustrates schematically the domains of transcripts mapped in the $\mathrm{S}$ component to date. Singlestranded RNA probes used for Northern blot and RNase protection assay are represented by green arrows. Primers used for RT-PCR analysis are represented by blue arrowheads.

\section{The $U_{5} 5-1$ transcript is expressed with $\gamma_{2}$ kinetics}

In the experiments described next, we evaluated the timing and requirements for the expression of the $\mathrm{U}_{\mathrm{S}} 5-1$ RNA. In the first series of experiments, RSC were exposed to 10 PFU of HSV-1(F) per cell, RNA extracted 1, 3,6 , or $9 \mathrm{~h}$ later and subjected to northern blot analysis using probe 2 for detection of the $\mathrm{U}_{\mathrm{S}} 5-1$ transcript. The results (figure $4 \mathrm{~A}$ ) show that the $\mathrm{U}_{\mathrm{S}} 5-1$ could not be detected at 1 or $3 \mathrm{~h}$ after infection. It was first detected at $6 \mathrm{~h}$ after infection.

In the next series of experiments we determined whether the onset of synthesis of $\mathrm{U}_{\mathrm{S}} 5-1$ requires de novo viral protein synthesis. RSC were infected with $10 \mathrm{PFU}$ of HSV-1(F) per cell in the presence or absence of $100 \mu \mathrm{g} / \mathrm{ml}$ cycloheximide. Total RNA was extracted $9 \mathrm{~h}$ later and subjected to northern blot analysis. Addition of cycloheximide completely abrogated the expression of the $\mathrm{U}_{5} 5-1$ transcript (Fig. 4B), indicating that de novo protein synthesis is essential for its expression.

The purpose of the next series of experiments was to determine whether viral DNA synthesis was required for the synthesis of $\mathrm{U}_{\mathrm{S}}$ 5-1 RNA. RSC were exposed to $10 \mathrm{PFU}$ of HSV-1(F) per cell in the presence or absence of $300 \mu \mathrm{g}$ of PAA per ml. Total RNA was extracted $9 \mathrm{~h}$ later and subjected to northern blot analysis. PAA completely abrogated the expression of the $\mathrm{U}_{S} 5-1$ transcript (Fig. $4 \mathrm{C})$, indicating that the replication of viral DNA is essential for its expression, and therefore that the $\mathrm{U}_{\mathrm{S}} 5-1$ transcript is expressed with $\gamma$ kinetics. Since the expression of the RNA was completely abrogated in the presence of PAA and not just diminished we conclude that the $\mathrm{U}_{5} 5-1$ transcript is expressed with $\gamma_{2}$ kinetics. 


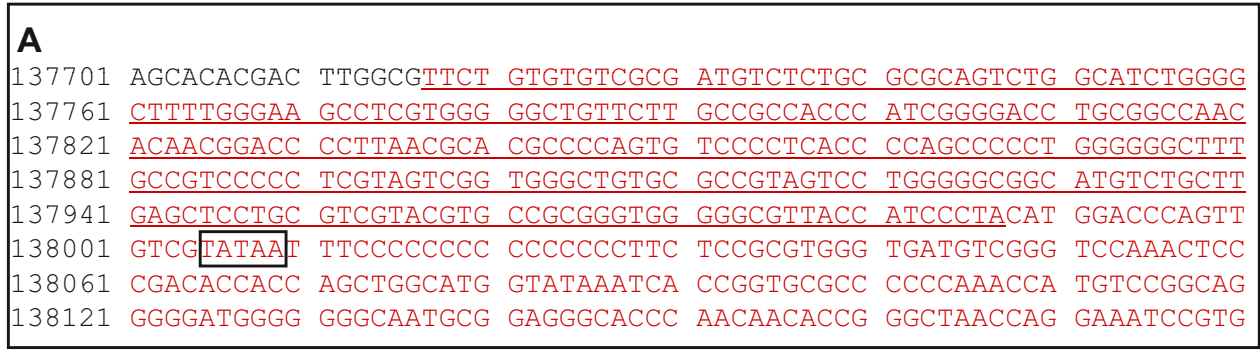

\section{B}

132601 CGGGCGGGGG GAAGCCACTG TGGTCCTCCG GGACGTTTTC TGGATGGCCG ACATTTCCCC 132661 AGGCGCTTTT GCGCCTTGTG TAAAAGCGCG GCGTCCCGCT CTCCGATCCC CGCCCCTGGG 132721 CACGCGCAAG CGCAAGCGCC CTTCCCGCCC CCTCTCATCG GAGTCTGAGG TAGAATCCGA 132781 TACAGCCTTG GAGTCTGAGG TCGAATCCGA GACAGCATCG GATTCGACCG AGTCTGGGGA 132841 CCAGGATGAA GCCCCCCGCA TCGGTGGCCG TAGGGCCCCC CGGAGGCTTG GGGGGCGGTT 132901 TTTTCTGGAC ATGTCGGCGG AATCCACCAC GGGGACGGAA ACGGATGCGT CGGTGTCGGA 132961 CGACCCCGAC GACACGTCCG ACTGGTCTTA TGACGACATT CCCCCACGAC CCAAGCGGGC 133021 CCGGGTAAAC CTGCGGCTCA CGAGCTCTCC CGATCGGCGG GATGGGG TTA TTTTTCCTAA 133081 GATGGGGCGG GTCCGGTCTA CCCGGGAAAC GCAGCCCCGG GCCCCCACCC CGTCGGCCCC 133141 AAGCCCAAAT GCAATGCTAC GGCGCTCGGT GCGCCAGGCC CAGAGGCGGA GCAGCGCACG 133201 ATGGACCCCC GACCTGGGCT ACATGCGCCA GTGTATCAAT CAGCTGTTTC GGGTCCTGCG 133261 GGTCGCCCGG GACCCCCACG GCAGTGCCAA CCGCCTGCGC CACCTGATAC GCGACTGTTA 133321 CCTGATGGGA TACTGCCGAG CCCGTCTGGC CCCGCGCACG TGGTGCCGTT TGCTGCAGGT 133381 GTCCGGCGGA ACCTGGGGCA TGCACCTGCG CAACACCATA CGGGAGGTGG AGGCTCGATT 133441 CGACGCCACC GCGGAACCCG TGTGCAAGCT TCCTTGTTTG GAGACCAGAC GGTACGGCCC 133501 GGAGTGTGAT CTTAGTAATC TCGAGATTCA TCTCAGCGCG ACAAGCGATG ATGAAATCTC 133561 CGATGCCACC GATCTGGAGG CCGCCGGTTC GGACCACACG CTCGCGTCCC AGTCCGACAC 133621 GGAGGATGCC CCCTCCCCCG TTACGCTGGA AACCCCAGAA CCCCGCGGGT CCCTCGCTGT 133681 GCGTCTGGAG GATGAGTTTG GGGAGTTTGA CTGGACCCCC CAGGAGGGCT CCCAGCCCTG 133741 GCTGTCTGCG GTCGTGGCCG ATACCAGCTC CGTGGAACGC CCGGGCCCAT CCGATTCTGG 133801 GGCGGGTCGC GCCGCAGAAG ACCGCAAGTG TCTGGACGGC TGCCGGAAAA TGCGCTTCTC 133861 CACCGCCTGC CCCTATCCGT GCAGCGACAC GTTTCTCCGG CCGTGAGTCC GGTCGCCCCG 133921 ACCCCCTTGT ATGTCCCCAA AATAAAAGAC CAAAATCAAA GCGTTTGTCC CAGCGTCTTA 133981 ATGGCGGGAA GGGCGGAGA AAACAGACCA CGCGGACATG GGGGGTGTTT GGGGGTTTAT 134041 TGGCACCGGG GGCTAAAGGG TGGTAACCGg ATAGCAGATG TGAGGAAGTC GGGGCCGTTC

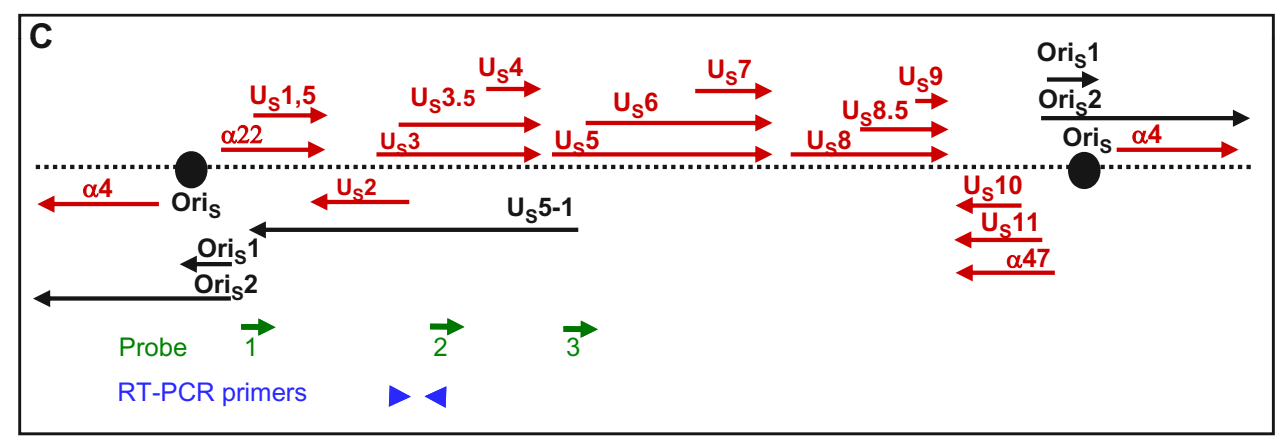

Figure 1 Genomic location of the $\mathbf{U}_{\mathbf{s}} \mathbf{5}-\mathbf{1}$ RNA. (A) In red is shown the sequence of the probe 3 , used for the determination of the $5^{\prime}$-end of the $\cup_{5} 5-$ 1 RNA. Underlined are first 270 bases of the probe 3, which was the size of the protected fragment in the RNase protection experiment to determine the 5'-end of the $U_{5} 5-1$ RNA. In the box is the sequence of potential TATA box. (B) In red is shown the sequence of the probe 1, used for the determination of the $3^{\prime}$-end of the $U_{5} 5-1$ RNA. Underlined are the last 180 bases of the probe 1, which was the size of the protected fragment. Sequence of a possible polyadenylation signal for the $U_{5} 5-1$ transcript is shown in the box. (C) Location and the direction of transcription of RNAs expressed from the unique-short region are represented by arrows. Red arrows represent protein-coding RNAs, black arrows represent non-coding RNAs. Location and the direction of the transcription of the single-stranded RNA probes used in the experiments described in this report are represented by green arrows. Primers used for RT-PCR detection of $\mathrm{U}_{5} 5-1$ transcript are shown in blue arrowheads. 


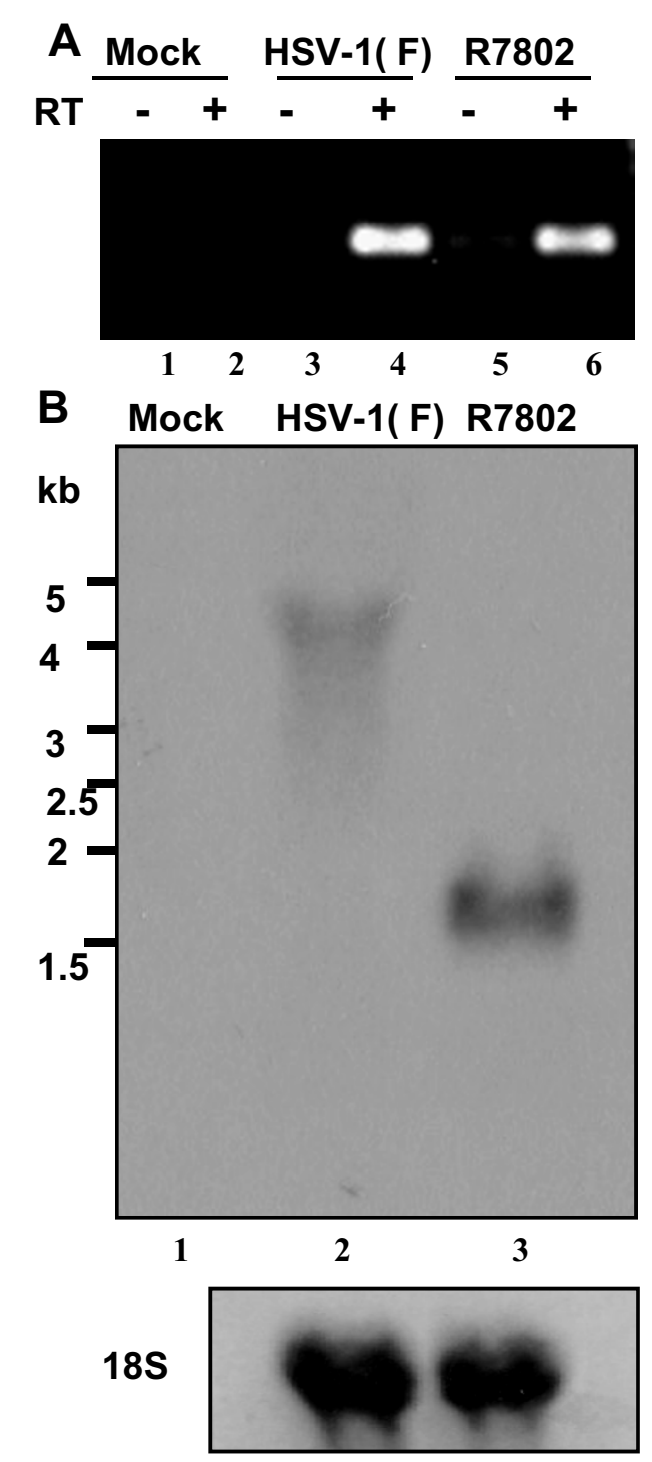

Figure $2 \mathrm{~A}$ RNA antisense to $\mathrm{U}_{\mathrm{s}} \mathbf{3}$ accumulates in cells infected with wild-type virus. (A) Cultures of RSC in $25 \mathrm{~cm}^{2}$ flasks were mock infected (lanes 1 and 2) or infected with 10 PFU of HSV-1 (F) (lanes 3 and 4) or R7802 (lanes 5 and 6) per cell. Total RNA was extracted $18 \mathrm{~h}$ later and reverse transcription was performed on $1 \mu \mathrm{g}$ of total RNA. As a control, $1 \mu \mathrm{g}$ of RNA was subjected to the same treatment, except that reverse transcriptase was omitted (lanes 1, 3, and 5). (B) Cultures of RSC in $25 \mathrm{~cm}^{2}$ flasks were either mock infected (lane 1) or infected with 10 PFU of HSV-1 (F) (lane 2) or R7802 (lane 3) per cell. Total RNA was extracted $18 \mathrm{~h}$ later and aliquots of $10 \mu \mathrm{g}$ of total RNA were separated on $1 \%$ formaldehyde agarose gel, transferred to Biodyne B nylon membrane and hybridized with single-stranded RNA probe 2. For the size determination molecular weight marker positions are shown. The amount of $18 \mathrm{~S}$ ribosomal RNA is shown as the loading control.

\section{The $\mathrm{U}_{\mathrm{s}} 5-1$ transcript has a half-life of about 80 minutes}

In the final set of experiments we proceeded to evaluate the stability of the $\mathrm{U}_{\mathrm{S}} 5-1$ transcript. RSC were infected with 10 PFU of HSV-1(F) per cell. At $6 \mathrm{~h}$ after infection the cells were exposed to $100 \mu \mathrm{g}$ of actinomycin D per ml of medium. The RNA was extracted at $0,1,2,3$ or $4 \mathrm{~h}$ after the addition of the actinomycin $\mathrm{D}$ and subjected to northern blot analysis (Fig. 4D). The intensity of individual bands was measured by a densitometer and plotted as a function of time (Fig. 4E). The results shown in figure $4 \mathrm{E}$ indicate that the half-life of the $\mathrm{U}_{\mathrm{S}} 5-1$ transcript was approximately $80 \mathrm{~min}$.

\section{Discussion}

Relevant to this report are the following:

(i) One possible explanation for the failure to detect the $4.5 \mathrm{~kb}$ RNA in earlier studies is the failure of transfer of high molecular weight RNA from gels containing high concentrations of agarose. In the studies reported here, we detected the $4.5 \mathrm{~kb}$ RNA on transfer from gels containing $1 \%$, or less, of agarose (Fig. 2C), but not following transfer from gel containing $1.2 \%$ agarose (data not shown).

(ii). The $\mathrm{U}_{\mathrm{S}} 5-1$ RNA is dependent on viral DNA synthesis for its accumulation. In contrast, the $\mathrm{Ori}_{S} 1$ RNA does not require de novo viral protein or DNA synthesis for its accumulation [10]. The measured half-life $(80 \mathrm{~min}$.) is in the line with that of other HSV-1 RNAs reported to be between 60 and 150 minutes regardless of the kinetic group to which a gene belongs [11].

(iii). In principle, viruses evolve continuously and do not retain DNA sequences that have no functions related to their survival in nature. The function of $\mathrm{U}_{S} 5-1$ RNA is not known. The $\mathrm{U}_{\mathrm{S}} 5-1 \mathrm{RNA}$ contains only two large ORFs of $300+$ codons. An ORF of approximately the same size is present in the corresponding sequences of HSV-2 DNA. However, In HSV-1 DNA the first large ORF initiates with the fifth methionine codon and its predicted amino acid sequences is not conserved in the corresponding HSV-2 ORF. We cannot exclude the possibility that the very small ORFs upstream of the large one are expressed. It seems it would be very unlikely that an RNA $4.5 \mathrm{~kb}$ long would encode a peptide with less than 100 amino acids, as it would be highly energy inefficient. However, it would not be unprecedented, since Drosophila's tal gene expresses $1.5 \mathrm{~kb}$ long transcript that codes for several 11 amino acid long peptides [12]. Overall, the data do not currently support the hypothesis that the $\mathrm{U}_{\mathrm{S}}$ 5-1 directs protein synthesis. 


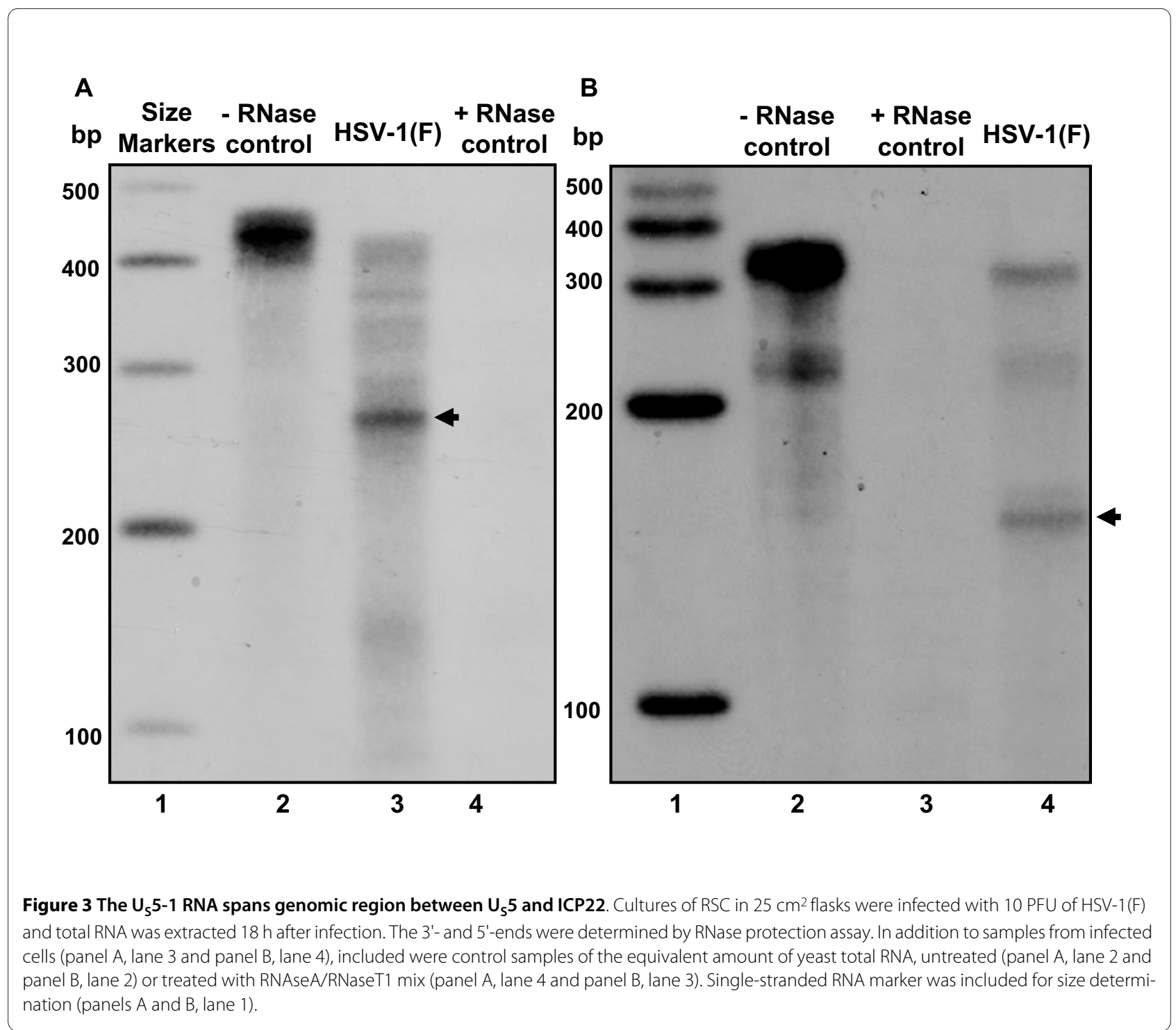

(iv) As noted earlier, the accumulation of HSV-1 non coding RNAs is not unprecedented. There is considerable current interest in non coding RNAs inasmuch as they frequently serve as precursors of microRNAs or directly regulate the expression of genes located antisense to the RNA. We should note however that none of the studies published to date reported microRNA derived from the domain of the $\mathrm{U}_{\mathrm{S}} 5-1$ RNA.

\section{Conclusion}

In this report we identified a novel HSV-1 transcript, expressed from the unique-short region of the viral genome. It spans the region from the $\mathrm{U}_{\mathrm{S}} 5$ to the $\alpha 22$ genes and is transcribed antisense to $\mathrm{U}_{\mathrm{S}} 5, \mathrm{U}_{\mathrm{S}} 4, \mathrm{U}_{\mathrm{S}} 3$ and $\alpha 22$ mRNAs, with $\gamma 2$ kinetics. Our data suggest that $U_{S} 5^{-}$ 1 is a long non-coding RNA. The role of this transcript is currently unknown, but it is plausible that, similarly to other long non-coding RNAs, it is involved in the regulation of expression of viral genes.

\section{Methods}

\section{Cells and viruses}

Rabbit skin cells (RSC) were originally obtained from J. McClaren. The cells were maintained in Dulbecco's modified Eagle's medium (DMEM) supplemented with 5\% fetal bovine serum. HSV-1(F) is the prototype HSV-1 strain used in the laboratory [13]. Mutant virus R7802, which has the deletion of the entire ICP22 ORF has been described elsewhere [14].

\section{Northern blot}

Cultures of RSC in $25-\mathrm{cm}^{2}$ flasks were either mock infected or infected with 10 PFU of virus per cell and maintained at $37^{\circ} \mathrm{C}$ in medium $199 \mathrm{~V}$ consisting of a mixture of 199 supplemented with $1 \%$ calf serum. The cells 


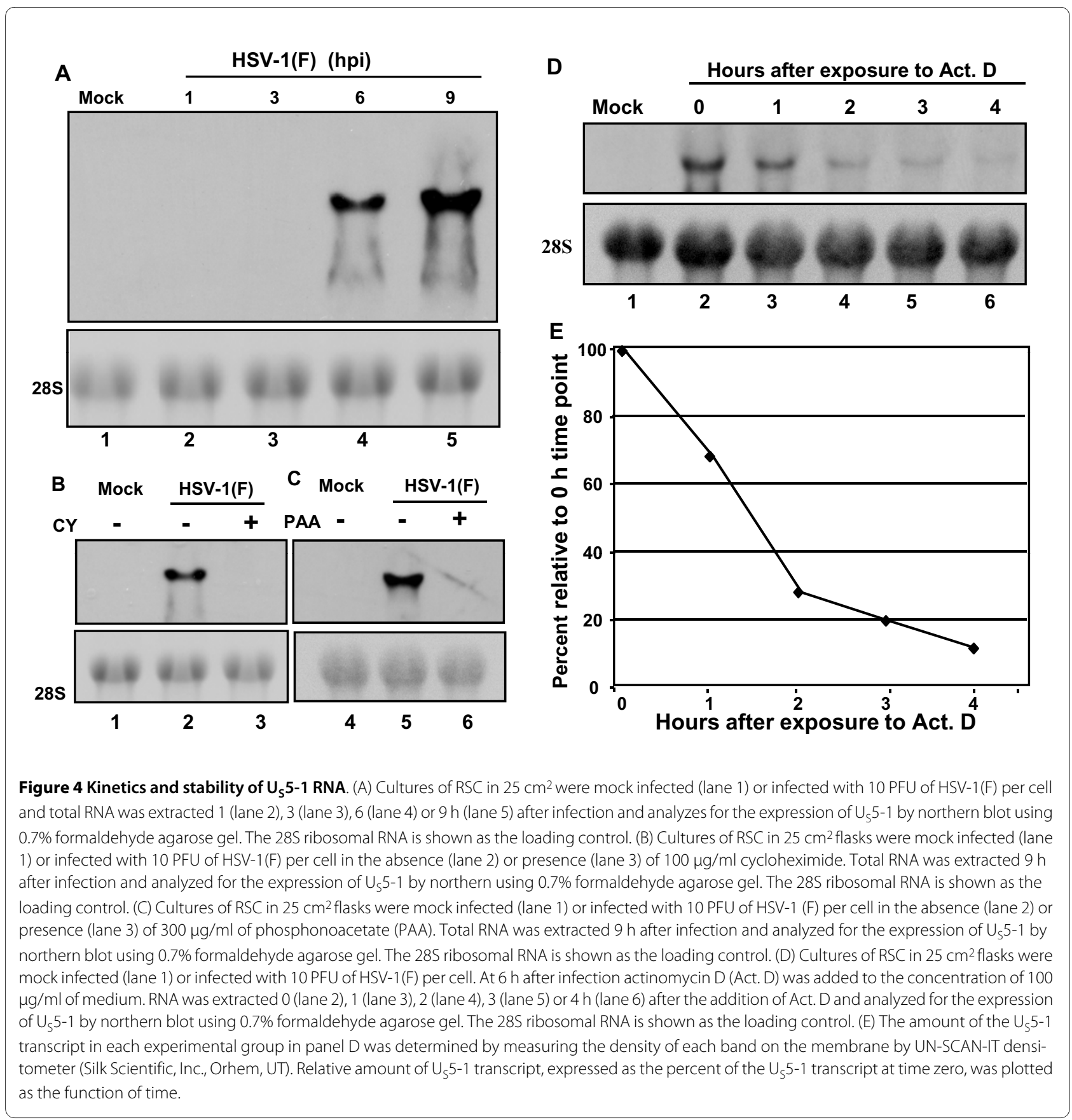

were harvested at time points after infection specified for each experiment. In some experiments cells were infected in the presence of $100 \mu \mathrm{g} / \mathrm{ml}$ cycloheximide or $300 \mu \mathrm{g} / \mathrm{ml}$ phosphonoacetate (PAA). Total RNA was extracted by using Trizol reagent (Invitrogen, Carlsbad, CA). Aliquots of $10 \mu \mathrm{g}$ of total RNA were separated on $1,2 \%, 1 \%$ or $0.7 \%$ formaldehyde agarose gels, transferred to Biodyne B nylon membranes (Thermo Science, Rockford, IL) and hybridized with single-stranded RNA probe transcribed in vitro and labeled with biotin using MAXIscript kit (Ambion, Austin, TX) from DNA template driven under the T7 promoter. DNA template was generated by PCR from the HSV-1 genomic DNA. Primers used for the generation of the DNA template were the following:

Probe 2(F): TAATACGACTCACTATAGGCATATACTAGCGCGGATGCCGCGGAC

Probe 2(R): CATGCCAGTCACCAGCTTGGCCATG-

\section{GTCGA}

PCR reaction was performed using Pfu DNA polymerase (Stratagene, La Jolla, CA) under the following conditions: $2 \mathrm{~min}$. at $94^{\circ} \mathrm{C}$ followed by 30 cycles of $30 \mathrm{~s}$ at $94^{\circ} \mathrm{C}, 30 \mathrm{~s}$ at $60^{\circ} \mathrm{C}, 1 \mathrm{~min}$ at $68^{\circ} \mathrm{C}$, with final $7 \mathrm{~min}$ at $68^{\circ} \mathrm{C}$. 
The location of the probe 2 within the unique-short region of the HSV-1 genome and the direction of its transcription is shown in figure $1 \mathrm{C}$.

\section{RNase Protection assay}

RNA samples were prepared as described for northern blot experiments. RNase protection assay was performed using RPA III kit (Ambion, Austin, TX) according to manufacturer's instructions. Briefly, aliquots of $10 \mu \mathrm{g}$ of total RNA were mixed with $2 \times 10^{4} \mathrm{cpm}$ of probe labeled with ${ }^{32}$ P-UTP using MAXIscript protocol (Ambion, Austin, TX) according to manufacturer's instructions and precipitated. RNA samples were dissolved in hybridization buffer, incubated at $56^{\circ} \mathrm{C}$ over night and treated with RNaseA/RnaseT1 mix (1:150 dilution) for 30 minutes. RNA was precipitated, dissolved in loading buffer, separated on $5 \%$ acrylamide $/ 8 \mathrm{M}$ urea gel and exposed to Kodak blue-bio autoradiography film (Denville Scientific, Metuchen, NJ). DNA templates from which the probe 1 for identification of the 3 -end or probe 3 for identification of the 5'-end of the $\mathrm{U}_{\mathrm{S}} 5-1$ RNA were transcribed were generated by PCR from the HSV-1 genomic DNA using primers for probe 1 :

P1(F):

TAATACGACTCACTATAG-

GCATATACTTTCTGTGTGTCGCGATGT

P1(R): AGTTTGTACACGGATTTCCTGGTTAG

and for probe 3 :

P3(F): TAATACGACTCACTATAGGCATATACATGTCGGCGGAATCCACC

P3(R): AGTTTGTAATTGATACACTGGCGCAT for probe 3

For the PCR reactions Pfu DNA polymerase was used (Stratagene, La Jolla, CA) under the following conditions: $2 \mathrm{~min}$. at $94^{\circ} \mathrm{C}$ followed by 30 cycles of $30 \mathrm{~s}$ at $94^{\circ} \mathrm{C}, 30 \mathrm{~s}$ at $60^{\circ} \mathrm{C}, 1 \mathrm{~min}$ at $68^{\circ} \mathrm{C}$, with final $7 \mathrm{~min}$ at $68^{\circ} \mathrm{C}$. The location of the probe 1 and probe 3 within the unique-short region of the HSV-1 genome and the direction of their transcription is shown in figure $1 \mathrm{C}$.

\section{Reverse-transcription PCR}

RNA samples were prepared as described for northern blot experiments. Reverse transcription was performed on $1 \mu \mathrm{g}$ of total RNA using Reverse Transcription System (Promega, Madison, WI) according to manufacturer's instructions. Primer used for reverse transcription was 51(R): ATGTACGGAAACCAGGACTACC. As a control, the same amount of RNA was subjected to the same treatment, except that reverse transcriptase was omitted. For PCR amplification the following primers were used: 51(R) and 51(F): TCCCGGCTGCGTCGTCGTATAC

All PCR reactions were performed using Pfu DNA polymerase (Stratagene, La Jolla, CA) under the following conditions: $2 \mathrm{~min}$. at $94^{\circ} \mathrm{C}$ followed by 30 cycles of $30 \mathrm{~s}$ at $94^{\circ} \mathrm{C}, 30 \mathrm{~s}$ at $60^{\circ} \mathrm{C}, 1 \mathrm{~min}$ at $72^{\circ} \mathrm{C}$, with final $7 \mathrm{~min}$ at $72^{\circ} \mathrm{C}$.
PCR products were separated on $1 \%$ agarose gel and visualized by ethidium-bromide staining. The location of primers used for RT-PCR within the unique-short region of the HSV-1 genome is shown in figure 1C.

\section{Half-life studies}

Cultures of RSC in $25-\mathrm{cm}^{2}$ flasks were either mock infected or infected with $10 \mathrm{PFU}$ of virus per cell and $6 \mathrm{~h}$ after infection actinomycin D (AcD) was added to the concentration of $100 \mu \mathrm{g} / \mathrm{ml}$. RNA was extracted $1,2,3$ or $4 \mathrm{~h}$ after the addition of AcD as processed for northern blot analysis. The intensity of the bands on the film was measured by UN-SCAN-IT densitometer (Silk Scientific, Inc., Orhem, UT) and relative amount calculated as the percentage of RNA present at the time of the addition of AcD was plotted as the function of time.

\section{Competing interests}

The authors declare that they have no competing interests.

\section{Authors' contributions}

VJ performed the experiments and drafted the manuscript. BR reviewed and revised the manuscript.

\section{Acknowledgements}

Thee studies were aided by a grant from The National Cancer Institute 2R01 CA088860

\section{Author Details}

The Marjorie B. Kovler Viral Oncology Laboratories, The University of Chicago, Chicago IL 60637, USA

Received: 20 March 2010 Accepted: 21 May 2010

Published: 21 May 2010

\section{References}

1. McGeoch DJ, Dolan A, Donald S, Rixon FJ: Sequence determination and genetic content of the short unique region in the genome of herpes simplex virus type 1. J Mol Biol 1985, 181:1-13.

2. Georgopoulou U, Michaelidou A, Roizman B, Mavromara-Nazos P: Identification of a new transcriptional unit that yields a gene product within the unique sequences of the short component of the herpes simplex virus 1 genome. J Virol 1993, 67:3961-3968.

3. Carter KL, Roizman B: The promoter and transcriptional unit of a novel herpes simplex virus 1 alpha gene are contained in, and encode a protein in frame with, the open reading frame of the alpha 22 gene. $J$ Virol 1996, 70:172-178.

4. Poon AP, Roizman B: Herpes simplex virus 1 ICP22 regulates the accumulation of a shorter mRNA and of a truncated US3 protein kinase that exhibits altered functions. J Virol 2005, 79:8470-8479.

5. Hubenthal-Voss J, Starr L, Roizman B: The herpes simplex virus origins of DNA synthesis in the $S$ component are each contained in a transcribed open reading frame. $J$ Virol 1987, 61:3349-3355.

6. Stevens JG, Wagner EK, Devi-Rao GB, Cook ML, Feldman LT: RNA complementary to a herpesvirus alpha gene mRNA is prominent in latently infected neurons. Science 1987, 235:1056-1059.

7. Dolan A, Jamieson FE, Cunningham C, Barnett BC, McGeoch DJ: The genome sequence of herpes simplex virus type 2. J Virol 1998, 72:2010-2021.

8. Wechsler SL, Nesburn AB, Zwaagstra J, Ghiasi H: Sequence of the latencyrelated gene of herpes simplex virus type 1. Virology 1989, 168:168-172.

9. Yeh L, Schaffer PA: A novel class of transcripts expressed with late kinetics in the absence of ICP4 spans the junction between the long and short segments of the herpes simplex virus type 1 genome. $J$ Virol 1993, 67:7373-7382

10. Voss JH, Roizman B: Properties of two 5'-coterminal RNAs transcribed part way and across the $S$ component origin of DNA synthesis of the 
herpes simplex virus 1 genome. Proc Natl Acad Sci USA 1988 85:8454-8458.

11. Oroskar AA, Read GS: Control of mRNA stability by the virion host shutoff function of herpes simplex virus. J Virol 1989, 63:1897-1906.

12. Galindo MI, Pueyo JI, Fouix S, Bishop SA, Couso JP: Peptides encoded by short ORFs control development and define a new eukaryotic gene family. PLOS Biol 2007, 5:e106.

13. Ejercito PM, Kieff ED, Roizman B: Characterization of herpes simplex virus strains differing in their effects on social behaviour of infected cells. J Gen Virol 1968, 2:357-364.

14. Ogle WO, Roizman B: Functional anatomy of herpes simplex virus 1 overlapping genes encoding infected-cell protein 22 and US1.5 protein. J Virol 1999, 73:4305-4315.

\section{doi: 10.1186/1743-422X-7-103}

Cite this article as: Jovasevic and Roizman, The novel HSV-1 US5-1 RNA is transcribed off a domain encoding US 5, US 4, US 3, US 2 and ?22 Virology Journal 2010, 7:103

Submit your next manuscript to BioMed Central and take full advantage of:

- Convenient online submission

- Thorough peer review

- No space constraints or color figure charges

- Immediate publication on acceptance

- Inclusion in PubMed, CAS, Scopus and Google Scholar

- Research which is freely available for redistribution

Submit your manuscript at www.biomedcentral.com/submit
C Biomed Central 